\title{
凝集状態のキラリティーを測定できる分光計の開発
}

\author{
東京理科大学研究推進機構総合研究院 黒田玲子
}

\section{Reiko KURODA: Development of Chiroptical Spectrophotometers which can Measure Condensed Phases}

Molecular chirality realizes strongly in the condensed phases (crystals, membranes, gels), however, it cannot be generally measured by commercially-available spectrophotometers due to strong macroscopic anisotropies. We have developed novel Universal Chiroptical Spectrophotometers, UCS-1 $\sim 3$, which overcome these problems. UCS-1 provides all optical characteristics. UCS-2/3 measure transmittance and Diffuse Reflectance CD, with vertical incident light and a horizontal sample stage, ideal for a droplet of solutions, loose powders or gel, to reveal structures and the dynamics of the transition processes. In this article, I shall describe the difficulty of solid-state chirality measurements, principles/outlines of UCSs and several examples of rich information obtained using UCSs.

\section{1.はじめに}

\section{1 分子あるいはその集合体のキラリティー}

靴のように鏡像対掌体 (右の靴と左の靴の関係) が別 であることをキラル，靴下のように同じであることをア キラルという.キラルな性質をもつ物質があることが最 初に発見されたのは水晶についてである.1812年, Biot が結晶面の出方が互いに鏡像対掌の右水晶と左水晶に 直線偏光を当てたところ, 透過光の偏光面が右に回転 （右旋性）あるいは左に回転（左旋性）した，その後，液 体状態でもキラリティーがあることが示され，キラリ ティーは分子の特性であることが判明した. キラル分光 はもっぱら溶液状態の分子に関する研究を扱い, 分子の 絶対構造や光学純度の簡便な判別手段として広く使わ れるようになった。一方で, キラリティーの発見が結晶 でなされたにもかかわらず, 固体状態でのキラリティー 研究は少数派となっていった.

\section{2 何故凝集状態が重要なのか?}

固体中で分子 (本稿では原子・イオンも含めた広義の 分子）は熱振動をしているもののその動きは液体, 気体 と比べれば大幅に制限されて㧍り，隣接した分子の影響 を大きく受ける。このため, 固体状態の分子は溶液状態 とは異なった構造をとったり, ユニークな化学反応を起 こしたりする. また, 水晶 $\mathrm{SiO}_{2}$ は $\mathrm{Si}$ とOから構成されて おりキラルな分子は存在しないが, 原子の配列の仕方に より，結晶状態ではじめてキラリティーが現れる。一方 で, タンパクと核酸がキラルであることを利用して，こ れら生体の基本物質の高次構造を溶液のキラリティー を使って調べることができるが, $\beta$-アミロイドのような 日本結晶学会誌 第 60 巻 第 4 号 $(2018)$
繊維を形成したタンパクの構造は凝集状態での構造を調 べる必要がある。このように,アキラルあるいはキラル な構成要素 (分子, イオン, 原子)のキラルな集合体のキ ラリティーの研究から, 溶液中の分子のキラリティーに 勝るとも劣らない重要な知見が得られる.

分光測定は一般に溶液状態で行われ, 単結晶X線構造 解析で得られた分子構造を参照するのが普通である。し かし, 前述のようにこの $2 つ の$ 状態で分子が同じ構造·挙 動をとるとは必ずしも限らない. 特にキラル分光は構造の 違いに非常に敏感である. 大学院生時代にこのことに気 づき, 博士論文の研究テーマの半分はキラルな金属錯体 の固体状態でのキラル分光測定に当てた. それから約 45 年間, 途中キラル分光研究に従事しなかった時期も一時 あったが, 固体状態におけるキラル分光装置の開発, 測定 方法の開発と応用の研究を行ってきた. 研究対象は, 無 機物質, 有機物質, 生体物質とすべてにわたり, 単結晶, 粉末結晶, 膜, ゲル状態での測定を可能にすることがで きた. 本稿では, 凝集状態のキラル分光の問題点, それを 解決できる装置の開発, 応用例について解説する。

\section{2. 凝集状態のキラリティー測定}

\section{1 何故凝集状態の測定が困難なのか?}

キラリティーは右回り, 左回りの円偏光に対する吸 光係数の差である CD (circular dichroism, 円二色性)を $50 \mathrm{kHz}$ の信号として観測する。後述するように, ストー クスベクトル1) とミューラー行列2)を用いた解析により

Signal $50 \mathrm{kHz}=\mathrm{G}_{1}\left(\mathrm{P}_{\mathrm{x}}^{2}+\mathrm{P}_{\mathrm{y}}^{2}\right)\left[\mathrm{CD}+1 / 2\left(\mathrm{LD}^{\prime} \mathrm{LB}-\mathrm{LDLB}^{\prime}\right)\right]$ $+\mathrm{G}_{1}\left(\mathrm{P}_{\mathrm{x}}^{2}-\mathrm{P}_{\mathrm{y}}^{2}\right) \sin 2 \mathrm{a}\left(-\mathrm{LB} \cos 2 \theta+\mathrm{LB}^{\prime} \sin 2 \theta\right)$ 
と，表される、3)ここで LD, LBはそれぞれ $(x-y)$ 直線二 色性 (linear dichroism), $(\mathrm{x}-\mathrm{y})$ 直線複屈折 (linear birefringence)，LD'，LB'はそれぞれ $\left(45^{\circ}-135^{\circ}\right)$ 直線二色性, $\left(45^{\circ}-135^{\circ}\right)$ 直線複屈折, また $\mathrm{P}_{\mathrm{x}}^{2}, \mathrm{P}_{\mathrm{y}}^{2}$ はそれぞれ $\mathrm{x}, \mathrm{y}$ 軸 に対する光電子増倍管 $(\mathrm{PM})$ の密板の透過率で, $\mathrm{a}$ は $\mathrm{x}$ 軸に関するPMの方位角, $\theta$ はサンプルの回転角である。 溶液のような均一な状態では, $\mathrm{LD}, \mathrm{LB}, \mathrm{LD}^{\prime}, \mathrm{LB}^{\prime}$ は 0 であるが，固体状態のように本質的に巨視的異方性をも つ試料では, これらの值が $\mathrm{CD}$ の数百倍になることもあ る. 固体状態でユニークに現れるCDを測定するために は，固体状態で測定する必要があるが，巨視的異方性の 項の存在を忘れ，市販の分光計で測定した異方性による シグナルを含んだスペクトルが報告されることもあり， 看過できない. 正しいスペクトルを得るには, 式 (1)の $\mathrm{CD}$ 以外の項を消去するか, $\mathrm{CD}$ シグナルのみを観測する ようにするかの工夫が必要となる。

\section{2 異方性を含まない測定が可能な試料}

\subsection{1 特殊な単結晶の測定 ${ }^{4), 5}$}

等軸晶系の結晶軸（ただし 4.2 参照）あるいは正方晶 系, 六方晶系のような単軸晶系の単軸に垂直な面では 異方性がない.したがって, これらの結晶軸方向に円偏 光を入射させると, 光路に垂直な面での異方性は 0 とな り, 観測される $\mathrm{CD}$ シグナルには異方性による偽のシグ ナルは含まれず，正しいCDスペクトルが観測できる。 しかし, 結晶内の分子の配向により, 許容される電子遷 移の種類が限られることがある，例えば，D3対称をもつ $\mathrm{Co}$ (III) 錯体の第一吸収带領域での d- 電子エネルギーは, $\mathrm{D} 3$ 配位子場で ${ }^{1} \mathrm{~T}_{1 \mathrm{~g}}$ 軌道が ${ }^{1} \mathrm{~A} 2$ と ${ }^{1} \mathrm{E}$ 軌道 (2重に縮退して いる）に分裂し， ${ }^{1} \mathrm{~A}_{1} \rightarrow{ }^{1} \mathrm{~A} 2$ 扮よび ${ }^{1} \mathrm{~A}_{1} \rightarrow{ }^{1} \mathrm{E}$ 遷移となる. どちらも磁気的に許容されるが, 電子的にはそれぞれC3 軸に平行扮よび垂直なときにのみ許容される。 そこで, 分子の $\mathrm{C} 3$ 対称軸と六方晶系結晶の $c$ 軸が平行であれば, 結晶軸方向に円偏光を入射させることで, Eバンドのみ が励起されることになる，その結果，バンドの帰属が行 え, さらに, その旋光強度 rotatory strength $R$ を求めるこ とができるという大きな利点がある、4)-6)一般に，大きな 正と負のピーク (今の例では ${ }^{1} \mathrm{~A}_{1} \rightarrow{ }^{1} \mathrm{~A} 2$ と ${ }^{1} \mathrm{~A}_{1} \rightarrow{ }^{1} \mathrm{E}$ 遷移) が近接して存在しているので, 分子がランダムに配向し ている溶液の CD スペクトルではそれらが打ち消しあっ た結果の一桁小さなピークとして観測される. CD スペ クトルが分子構造に敏感なゆえんでもある。図1左に $\Lambda-\left[\mathrm{Co}(\mathrm{en})_{3}\right] \mathrm{Br}_{3} . \mathrm{H}_{2} \mathrm{O}$ の溶液状態と光軸方向の単結晶の $\mathrm{CD}$ スペクトルを示す.4)-6) 溶液の $\mathrm{CD}$ は単結晶の $\mathrm{E}$ バンド よりも一桁小さいが(縦軸のスケールが溶液と結晶では 異なる), 主成分のピークの符号は一致している。一方, bis (tridentate $) \mathrm{Co}(\mathrm{III})$ 錯体である $\left[\mathrm{Co}((2 \mathrm{R}-\mathrm{Me})-\mathrm{tacn})_{2}\right]$ $\left(\mathrm{ClO}_{4}\right)_{3}$ の場合には（図1右）, 溶液の CD スペクトルは 単結晶と完全に逆符号で, あたかも絶対配置が逆転して
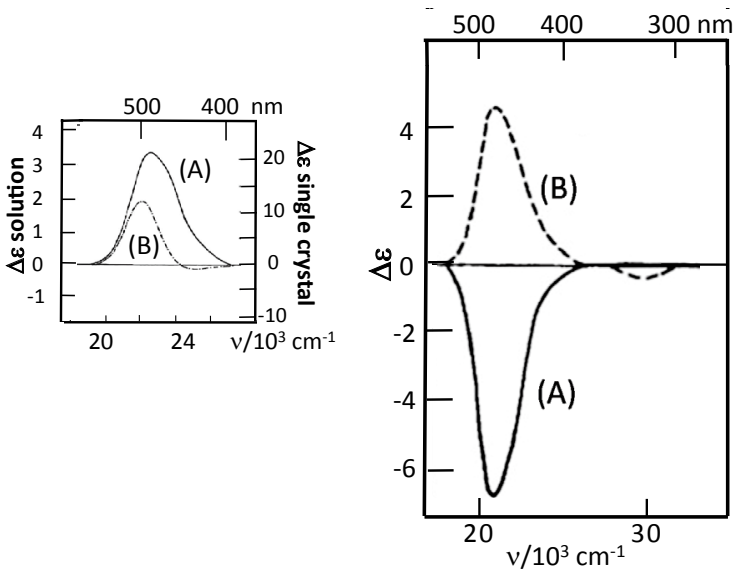

図1（A） $c$ 軸方向に入射した単結晶と（B）その溶液 の CD スペクトル. ((A) CD of a single crystal with radiation along the crystal $c$ axis and (B) its solution CD.) (left) $: \Lambda$ - $\left[\mathrm{Co}(\text { en })_{3}\right] \mathrm{Br}_{3} \cdot \mathrm{H}_{2} \mathrm{O}$; (right) $:[\mathrm{Co}(2 \mathrm{R}-$ $\left.\mathrm{Me})-\operatorname{tacn}]_{2}\right]\left(\mathrm{ClO}_{4}\right)_{3}$.

いるかのようである。この理由は, Co 原子周りの配位子 が正八面体場から大きく歪み極方向に配置して扮り, ま た，カウンターイオンとの相互作用により，Aバンドの 強度が増大しているためであると説明される。.

\subsection{2 粉末結晶 4)-66,8),9)}

上に記したように, 特定の結晶系の特定の方向のとき にのみ，異方性によるシグナルを含まないCDが測定で きる。しかし, 結晶を透過した光が十分な強度をもつよ うに結晶を薄く磨くのは非常に困難である.さらに, 異 方性を含まない単結晶の測定では許容される電子遷移 が限られ，一部の情報しか得られない。これらの問題を 解決するためには, 粉末結晶のCD スペクトルを測定す ればよいと着想した.4),5) 誌面の関係で今回は詳しくは 触れないが, 単結晶と粉末結晶（定量性が必要）のCD スペクトルと組み合わせる方法により, Co (III) 錯体の ${ }^{1} \mathrm{~A}_{1} \rightarrow{ }^{1} \mathrm{~A} 2$ と ${ }^{1} \mathrm{~A}_{1} \rightarrow{ }^{1} \mathrm{E}$ 遷移両方の帰属と旋光強度, 吸収 帯波長を求めることに成功し, 理論計算との比較が可能 となった.4)-7)

粉末結晶の CDを同じランダムに配向している溶液状 態との CD と比較すると, 溶媒の影響や隣接する分子の 影響の情報が得られるので興味深い，そこで粉末結晶の $\mathrm{CD} \mathrm{KBr}$ disc と nujol mullの両方で測定する方法を開 発した.4, $\left.\left.{ }^{4}, 6\right), 9\right)$ 粒子が小さくなり分散が小さくなるのは $\mathrm{KBr}$ disc 法である. 粒子の大きさ, disc生成時の圧力の 影響が強度も含めたスペクトルに及ぼす影響を博士論文 研究で調べた ${ }^{4)}$ Discの作り方によっては異方性が生じ る恐れがあるので, 後述のUCS 分光計を使って後に再検 討した。吕,8) 今では多くの人が当たり前に使うようになっ ている粉末結晶の CD の $\mathrm{KBr}$ discによる測定法を世界に 先駆けて開拓したことをうれしく思っている. 


\section{3. 凝集状態の全光学的性質が測定できる分光計 UCSの開発}

\section{1 一般の凝集状態の測定が可能な分光計の開発}

2.2では, 特殊な晶系の単結晶あるいは一般の結晶の 粉末結晶のCDスペクトルを測定する方法を取り扱っ た. しかし, 凝集状態には膜, ゲルなどの状態もあるし, $\mathrm{CD}$ 以外の $\mathrm{LB}, \mathrm{LD}, \mathrm{CB}$ にも，有用な知見が含まれてい る。そこで, 液体状態はもとより, 凝集状態全般における CD , CB（円複屈折＝ORD：Optical Rotatory Dispersion, 旋光分散), LD, LBのすべての光学的性質を測定でき る分光計を設計・作製し, Universal Chiroptical Spectrophotometer, UCS と命名した.3)

\section{2 測定装置UCS-1 の概要 3 (3) 10 )}

図2にわれわれの開発した装置, UCS-1のブロックダ イアグラムを示す（装置は神藤福井大学教授 (当時) と 日本分光(侏)との共同開発。国内特許取得)。市販の装置

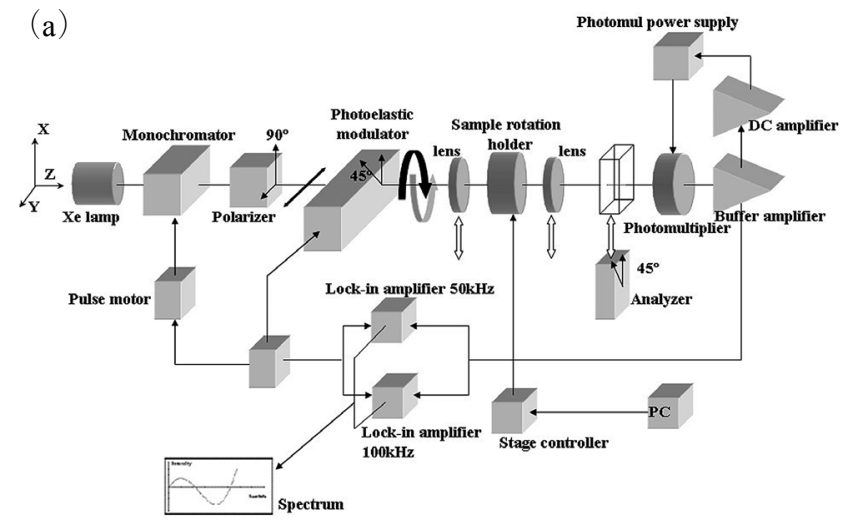

(b)

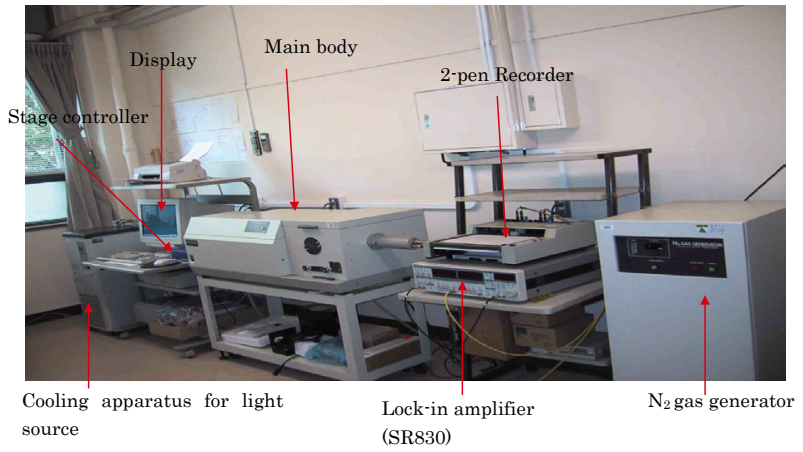

(c)

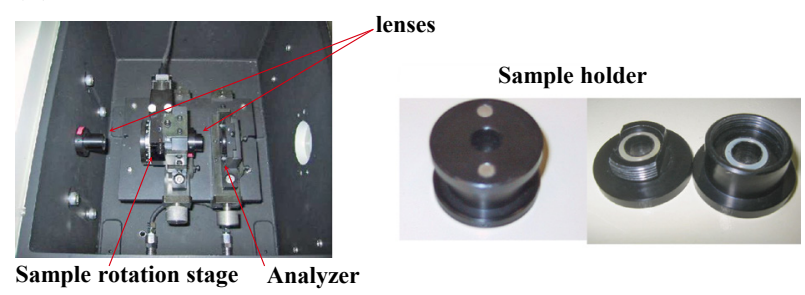

図2 UCS-1の（a）ブロックダイアグラム（b) 装置概 観. (c) 試料室とサンプルホールダー.（（a) Block diagram, (b) outlook and (c) the sample housing/a sample holder of UCS-1.)
からの代表的な改良点は，

(1) $50 \mathrm{kHz}, 100 \mathrm{kHz}$ のつのロックインアンプを搭載し, 両シグナルの同時測定が可能.

(2)外部からの信号に基づき，任意の角度で試料を入射光 路と直交する平面内で回転させてスペクトル取得が可 能. そのための，試料回転ホルダーを作製.

(3)試料ホルダーは, 試料回転ホルダーに自在に着脱可 能. 試料の表面側と裏面側に光照射可能.

(4)光変調器PEM (光弾性変調器) は, 静的残留複屈折 $\alpha$ が約 0.1 度の良質のものを選択.

(5)検光子も回転可能. また, 光路から離脱可能.

(6)検出器の光電子増倍管 (PM) は, 偏光特性が小さいも のを選択

である。

\subsection{1 測定の原理}

偏光変調分光計のシグナルの解析や装置の性能評価 に非常に有効なストークスベクトル1）とミューラー行 列2)を用いた。ストークスベクトル $\mathrm{S}=\left[\mathrm{S}_{0}, \mathrm{~S}_{1}, \mathrm{~S}_{2}, \mathrm{~S}_{3}\right]$ のパラメーターは, それぞれ, 光の強度, $45^{\circ}$ 方向優先 度, 右円偏光優先度, 水平方向優先度を示し, 以下のよ うに表される。

$$
\begin{aligned}
& \mathrm{S}_{0}=\mathrm{P}_{1 \mathrm{x}}^{2}+\mathrm{P}_{1 \mathrm{y}}^{2}=\mathrm{I}_{\mathrm{x}}+\mathrm{I}_{\mathrm{y}} \\
& \mathrm{S}_{1}=2 \mathrm{P}_{1 \mathrm{x}} \cdot \mathrm{P}_{1 \mathrm{y}} \cdot \cos \gamma \\
& \mathrm{S}_{2}=2 \mathrm{P}_{1 \mathrm{x}} \cdot \mathrm{P}_{1 \mathrm{y}} \cdot \sin \gamma \\
& \mathrm{S}_{3}=\mathrm{P}_{1 \mathrm{x}}^{2}-\mathrm{P}_{1 \mathrm{y}}^{2}=\mathrm{I}_{\mathrm{x}}-\mathrm{I}_{\mathrm{y}}
\end{aligned}
$$

ここで, $P_{1}, \gamma$ は, 光の振幅と位相を表す．われわれの UCS で観測されるすべての偏光現象 (LB, LD, CD, CB）は, サンプルの検出器で検出される光の強度 Id と して, 光電子増倍管 $\mathrm{D}$, サンプル $\mathrm{S}$, 光偏光変調器 $\mathrm{M}$, 偏光子 P のミューラー行列の積として記述することが できる. $\mathrm{I}_{0}$ は光源のストークスベクトルである .

$I_{\mathrm{d}}=\hat{D} \cdot \hat{S} \cdot \hat{M} \cdot \hat{P} \cdot \hat{I}_{0}$

$=1 / 2 \mathrm{I}_{0}\left(\mathrm{P}_{\mathrm{x}}^{2}+\mathrm{P}_{\mathrm{y}}^{2}\right)\left\{1+1 / 2\left(\mathrm{LD}^{\prime 2}+\mathrm{LD}^{2}\right)+[\mathrm{CD}+1 / 2\right.$

$\left.\left(\mathrm{LD}^{\prime} \mathrm{LB}-\mathrm{LB}^{\prime} \mathrm{LD}\right)\right] \sin (\delta+\alpha)+\left(\mathrm{LD}^{\prime} \sin 2 \theta-\mathrm{LD} \cos 2 \theta\right)$ $\cos (\delta+\alpha)\}+1 / 2 \mathrm{I}_{0}\left(\mathrm{P}_{\mathrm{x}}^{2}-\mathrm{P}_{\mathrm{y}}^{2}\right) \sin 2 \mathrm{a}\left\{-\left(\mathrm{LD}^{\prime} \cos 2 \theta-\mathrm{LD} \sin 2 \theta\right)\right.$ $+\left(\mathrm{LB}^{\prime} \sin 2 \theta-\mathrm{LB} \cos 2 \theta\right) \sin (\delta+\alpha)+\left[-\mathrm{CB}+1 / 2\left(\mathrm{LD}^{2}\right.\right.$ $\left.\left.+\mathrm{LB}^{2}-\mathrm{LD}^{\prime 2}-\mathrm{LB}^{\prime 2}\right) \sin 4 \theta+\left(\mathrm{LD}^{\prime} \mathrm{LD}+\mathrm{LB}^{\prime} \mathrm{LB}\right) \cos 4 \theta\right]$ $\cos (\delta+\alpha)\}+1 / 2 \mathrm{I}_{0}\left(\mathrm{P}_{\mathrm{x}}^{2}-\mathrm{P}_{\mathrm{y}}^{2}\right) \cos 2 \mathrm{a}\left\{\left(\mathrm{LD}^{\prime} \sin 2 \theta-\mathrm{LD} \cos 2 \theta\right)\right.$ $+\left(\mathrm{LB}^{\prime} \cos 2 \theta-\mathrm{LB} \sin 2 \theta\right) \sin (\delta+\alpha)+\left[1+1 / 2\left(\mathrm{LD}^{\prime 2}+\mathrm{LB}^{2}\right)\right.$ $\sin ^{2} 2 \theta+1 / 2\left(\mathrm{LD}^{2}+\mathrm{LB}^{\prime 2}\right) \cos ^{2} 2 \theta-2\left(\mathrm{LD}^{\prime} \mathrm{LD}+\mathrm{LB}^{\prime} \mathrm{LB}\right)$ $\sin 4 \theta] \cos (\delta+\alpha)\}$

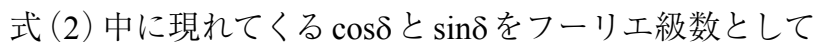
展開し，さらにわれわれの装置のPEM は静的残留複屈折 $\alpha$ が小さいために $\sin \alpha$ がかかている項は無視できるこ と, またPMの方位角 $\mathrm{a}$ を $\cos 2 \mathrm{a} \fallingdotseq 0$ になるようにベース ラインシフト調整でセットしているので $\cos 2 \mathrm{a}$ を含んで 
いる項も除去できることを考慮に入れると, $50 \mathrm{kHz}$ に調 節されたロックインアンプで検出されるシグナルは前出 の式（1）となる．詳しくは文献3）を参照いただきたい.

同様にして, ロックインアンプにより検出される光電 流の $100 \mathrm{kHz}$ 成分は

Signal $100 \mathrm{kHz}=\mathrm{G}_{2}\left(\mathrm{P}_{\mathrm{x}}^{2}+\mathrm{P}_{\mathrm{y}}^{2}\right)\left(\mathrm{LD}^{\prime} \sin 2 \theta-\mathrm{LD} \cos 2 \theta\right)+$ $\mathrm{G}_{2}\left(\left(\mathrm{P}_{\mathrm{x}}^{2}-\mathrm{P}_{\mathrm{y}}^{2}\right) \sin 2 \mathrm{a}\left\{-\mathrm{CB}+1 / 2\left(\mathrm{LD}^{2}+\mathrm{LB}^{2}-\mathrm{LD}^{\prime 2}-\mathrm{LB}^{\prime 2}\right)\right.\right.$ $\left.\sin 4 \theta+\left(\mathrm{LD}^{\prime} \mathrm{LD}+\mathrm{LB}^{\prime} \mathrm{LB}\right) \cos 4 \theta\right\}$

ここで $\mathrm{G}_{2}$ は $100 \mathrm{kHz}$ における分光計の感度に関する装置 定数である.

サンプルと PMの間にPEM と同じ $45^{\circ}$ の光軸で検光子 $\mathrm{A}$ を挿入した場合, ミューラー行列計算から PMで検出 される光の強度 $I_{\mathrm{d}}$ は $I_{\mathrm{d}}=\hat{D} \cdot \hat{A} \cdot \hat{S} \cdot \hat{M} \cdot \hat{P} \cdot \hat{I}_{0}$ で, 上と同様の 扱いで

Signal $50 \mathrm{kHz}=\mathrm{G}_{3}\left\{\mathrm{CD}+1 / 2\left(\mathrm{LD}^{\prime} \mathrm{LB}-\mathrm{LDLB}^{\prime}\right)-\mathrm{LB} \cos 2 \theta+\right.$ $\left.\mathrm{LB}^{\prime} \sin 2 \theta\right\}$

$\mathrm{G}_{3}$ は, 検光子を挿入したときの $50 \mathrm{kHz}$ における分光計の 感度に関する装置定数である. A は検光子のミューラー 行列を表す。また $100 \mathrm{kHz}$ シグナルも同様にして

Signal $100 \mathrm{kHz}=\mathrm{G}_{4}\left\{-\mathrm{LD}^{\prime} \sin 2 \theta+\mathrm{LD} \cos 2 \theta+\mathrm{CB}-1 / 2\right.$ $\left(\mathrm{LD}^{2}+\mathrm{LB}^{2}-\mathrm{LD}^{\prime 2}-\mathrm{LB}^{\prime 2}\right) \sin 4 \theta-\left(\mathrm{LDLD}^{\prime}+\mathrm{LBLB}^{\prime}\right) \cos 4 \theta$

$\mathrm{G}_{4}$ は，検光子を挿入したときの $100 \mathrm{kHz}$ における分光計 の感度に関する装置定数である.

式（1）が通常 CD, 式 (3) がLD, 式 (4) がLB, 式 (5) がCBとして通常, 観測に使われる信号である.

\subsubsection{UCS-1 測定法の開発}

固体サンプルのように大きな LB, LDが共存している $\mathrm{CD}, \mathrm{CB}$ を測定するためには，必要な信号のみを取り出 し余分の項を消すことができる測定・解析方法が必要で ある。本稿では, CD測定についてのみ説明する。

式（1）には，試料の回転に依存する $\theta$ を含む項と含ま ない項がある. 過去に,「試料を光の進行方向に垂直な面 内で種々の角度に回転させてスペクトル測定を行い, それ らを平均化すれば真のCDが得られる」という間違った記 述をした報文 ${ }^{11)}$ があり, 多くの研究がこの方法を踏襲し て誤ったスペクトルを報じる結果となってしまった。しか し, 回転に依存しない項があるので, これは正しくない.

われわれの測定法は，まず，吸収波長で試料を回転さ せてスペクトル (回転角依存スペクトル) を測定すること で, LDと PEMの残留ひずみとのカップリング, PMの偏 光特性と LB とのカップリングに起因する見かけのCD成 分が存在するかを確認する。もちろん, サンプルが不均 一であっても回転により值が変化するが, その場合には 下記による補正はできない，試料による吸収波長で検光
子を入れ Signal $100 \mathrm{kHz}$ の試料回転角依存スペクトルを 測定すると, 式 (5) から明らかなようにシグナルが $\cos 2 \theta$ で変化すればLD $>$ LB, $\sin 4 \theta て ゙$ 変化すればLD $\ll$ LBで あることが示される．測定法の詳細は文献3）を参照し ていただきたい，検光子をいれ，試料を回転しながら LB の試料回転角依存スペクトルを測定し, $\mathrm{LB}_{\max }$ の位置を 決める. そこから $45^{\circ}$ 回転した位置では $\mathrm{LB}=0, \mathrm{LB}^{\prime}=$ $\mathrm{LB}^{\prime}{ }_{\text {max }}$ となるので, この位置で $\mathrm{CD}$ スペクトルを測ると,

$$
\begin{aligned}
& {[\operatorname{appCD}] \text { face }=\mathrm{G}_{1}\left\{\left(\mathrm{P}_{\mathrm{x}}^{2}+\mathrm{P}_{\mathrm{y}}^{2}\right)\left[\mathrm{CD}-1 / 2 \mathrm{LDLB}^{\prime}\right]+\right.} \\
& \left.\left(\mathrm{P}_{\mathrm{x}}^{2}-\mathrm{P}_{\mathrm{y}}^{2}\right)\left(\sin 2 \mathrm{aLB}^{\prime}\right)\right\}
\end{aligned}
$$

試料の表裏を反転して波長スキャンをすると

$$
\begin{aligned}
& {[\text { appCD }] \text { back }=\mathrm{G}_{1}\left\{\left(\mathrm{P}_{\mathrm{x}}^{2}+\mathrm{P}_{\mathrm{y}}^{2}\right)\left[\mathrm{CD}+1 / 2 \mathrm{LDLB}^{\prime}\right]\right.} \\
& \left.\left(\mathrm{P}_{\mathrm{x}}^{2}-\mathrm{P}_{\mathrm{y}}^{2}\right) \sin 2 \mathrm{aLB}^{\prime}\right\}
\end{aligned}
$$

（6）と（7）を平均すると真の CDが得られる.

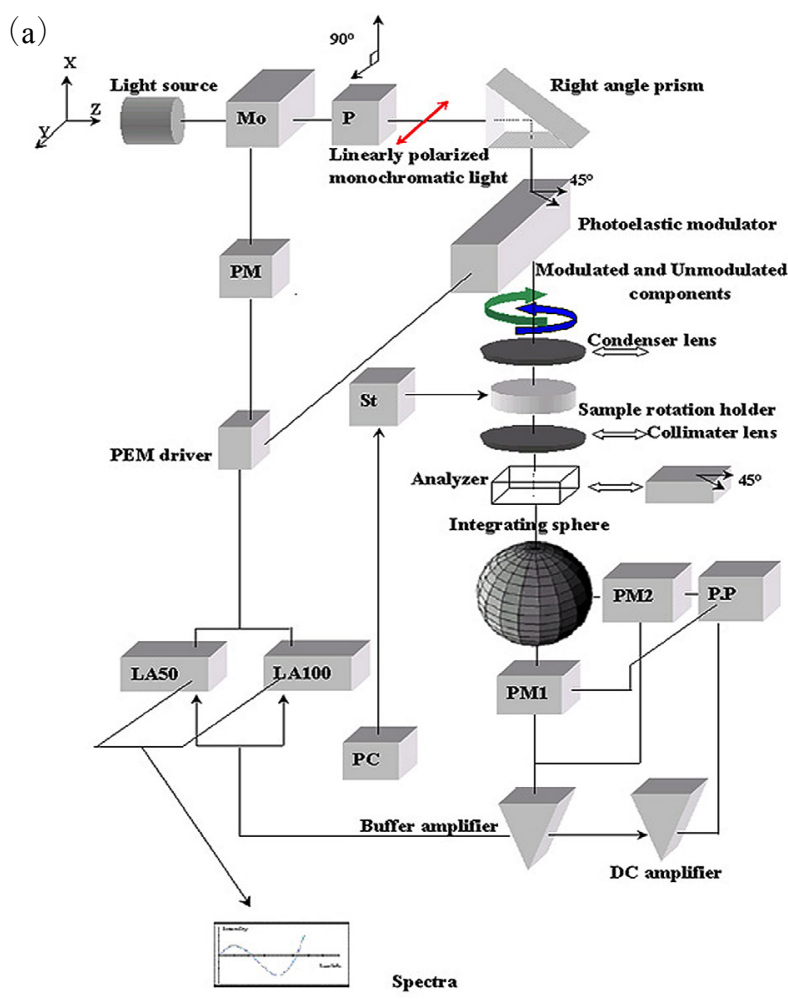

(b)

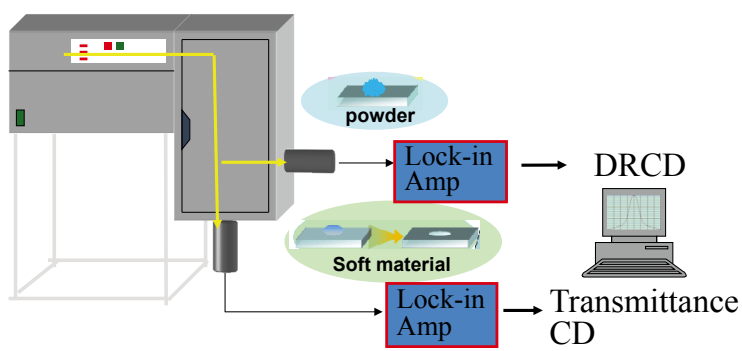

図3UCS-2/3の（a）ブロックダイアグラム. (b) 装置 概観と透過 CD と DRCD に対する入射光の進行方 向. ( (a) Block diagram and (b) outlook with light path for transmittance CD and DRCD for UCS-2/3.)

日本結晶学会誌 第 60 巻 第 4 号 (2018) 


\section{3 測定装置UCS-2/3の概要}

さらに, 試料を水平に置いて透過 $\mathrm{CD}$ 拉よび拡散反射 $\mathrm{CD}$ の両方の測定ができる装置, UCS-2, $\left.{ }^{12}\right) \mathrm{UCS}-3^{13)}$ を開 発した (国内特許取得)。装置のブロックダイアグラム を図3に示す. UCS-2 およびUCS-3 の特徵は, 光をプリ ズムによって $90^{\circ}$ 曲げて鉛直に走らせ, サンプルを水平 に置くことができるようにしたことである，ともに透過 $\mathrm{CD}$ および拡散反射 CD (DRCD) を測定できる. UCS-2 と UCS-3 の違いは, UCS-3 のほうが, 拡散反射球を改良し 感度を 20 倍とし, UCS-2では250〜800 nm までであった 測定領域を $190 〜 800 \mathrm{~nm}$ まで短波長領域に広げるなど 改善した点である。測定原理は上記のUCS-1 とほぼ同じ である. サンプルを水平に置くことで, 粉末, ゲルなど サンプル保持に重力の影響を受けるもの in situでのキラ リティー測定が可能となり, タンパク質が溶液から凝集 する過程や粉末結晶が時間とともに結晶状態を保ちつつ 変換していく現象の追跡など, リアルタイム測定を行う ことができるようになったことである. 驚くべき知見を 得ることができた，具体例をいくつか4. で紹介する.

\section{4 測定装置UCS と測定方法の検証}

Congo Red 吸着したポリビニルアルコール（PVA） フィルムはキラルではないが, 強い $\mathrm{CD}$ を示す。これは

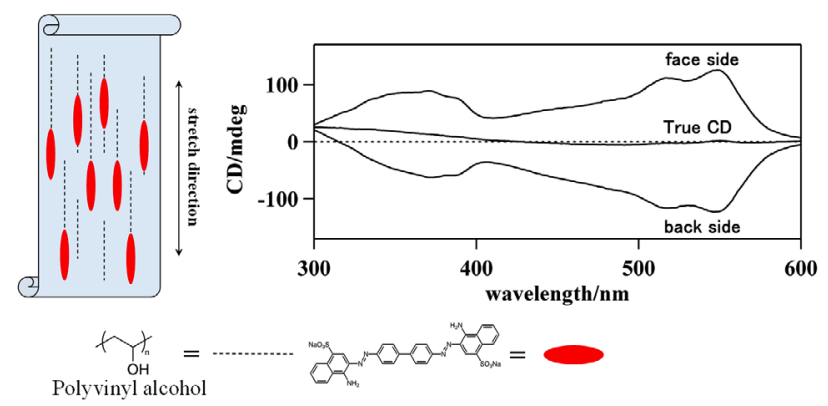

図4 Congo Redで染色したPVAフィルムの見かけの $\mathrm{CD}$ (表と裏) とその平均の真の $\mathrm{CD}$ スペクトル. (Apparent CD (face and back) of a PVA film died with Congo Red. The average of the two spectra gives true CD.)

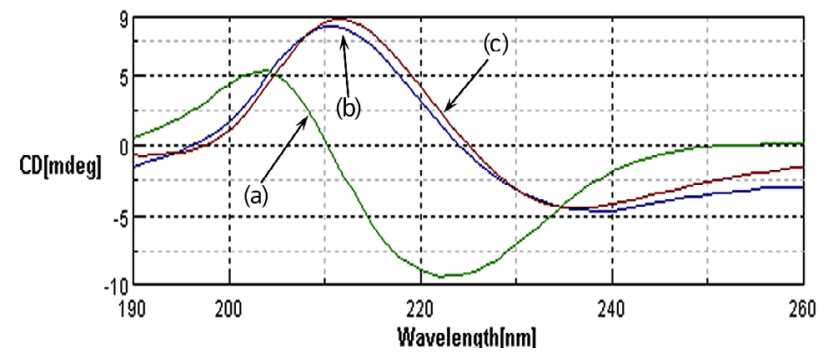

図5 UCS で測定した $\mathrm{A} \beta 40$ の L-B 膜の (a) CD と (b) CB お よび (c)Kramers-Kroenig変換によるCB スペクトル. (Comparison of (a) true $\mathrm{CD},(\mathrm{b})$ true $\mathrm{CB}$ and $(\mathrm{c}) \mathrm{CB}$ calculated based on Kramers-Kroenig relationship.)
すべて偽のピークである、サンプルが均一であれば強い 異方性があっても, 式(6)と（7）で表される試料の表, 裏 のスペクトルを測定するというわれわれの開発した測 定法により，偽のスペクトルを除去できるはずである. 図4に示したのがその一例で, 表の見かけの強い $\mathrm{CD}$, 裏 の見かけの強い $\mathrm{CD}$, そして, それらの平均として得ら れる真のCDスペクトルが示されている，真のCDスペ クトルは打ち消されてほぼゼロになっており，われわれ の測定装置と解析方法の正しいことが裏づけられた、3)

また, 異方性シグナルの混入しないCB スペクトルの

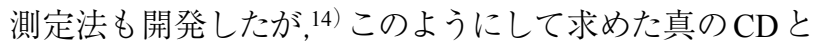
$\mathrm{CB}$ の間に吸収と分散の Kramers-Kronig の関係が成り立 つことを検証した。一例として, 図5にアルッハイマー 病の原因タンパクの 1 つである $\beta$-アミロイド 40 の 18 20 層積層した L-B 膜 (Langmuir- Blodgett) についての結 果を示すが, 良い一致を示している.14)

\section{UCS での測定例}

UCS 分光装置を用いて得られた知見の代表的例を以下 に示す. 有機物, 無機物, 生態関連物質, 結晶, 膜, ジェ ルと、多岐にわたる。

\section{1 結晶中での光反応の追跡}

8-Bromo-2-thioaryloxy-3-methylcyclohexen-1-one (1) は 軸不斉をもつ化合物で, 溶液中では単結合周りの回転が 容易に抄きるために，キラルではない(図6a). 光環化反 応を起こしてキラルな化合物 2 となるが, 溶液反応では ラセミ混合物が得られる。しかし, (-) - (R,R)-(-)-trans2,3-bis (hydroxy diphenyl methyl)-1,4-dioxaspiro-[4,4] nonane (3) と1:1のキラルな包摂結晶を作り, 化合物 1 のキラリティーを左右の一方に固定して固体状態で光反 応を行うと, ホスト化合物のキラリティーに依存して一方 のエナンチオマーが多く生成される (図6a)。この反応の 様子を結晶のCDスペクトルで追うと, ゲスト分子領域 に等吸収点をもったスペクトルが得られた（図6b）。8),9) 包摂結晶を溶液に溶かせば, キラルなホスト分子による 束縛がなくなり, 化合物 1 はアキラルとなる. 光路長の 長いセルを用いても，化合物 1 の CDピークはこの領域 にはまったく現れない (図6C). 固体状態でのCD スペク トルの強みを示す好例であろう。

\section{2 等軸晶系結晶は本当に光学的に均質だろうか?}

等軸晶系の結晶はどの方向からも光学的に均質であ り，巨視的異方性がないと信じられてきた。しかし，キ ラルなクラス $\mathrm{T}$ に属する等軸晶系結晶には複屈折がある ことを，真の $\mathrm{LB}$ 測定法を開発し, $\mathrm{NaClO}_{3}$ 結晶を用いて 初めて明らかにすることができた.15) [111] 方向にはLB はないが, [100]方向では, 図7に示すように, 結晶の厚 さに比例してLBを示す。しかも，われわれの手法で補 正された真の LB值と厚さには, 補正前のデータよりも 
(a)

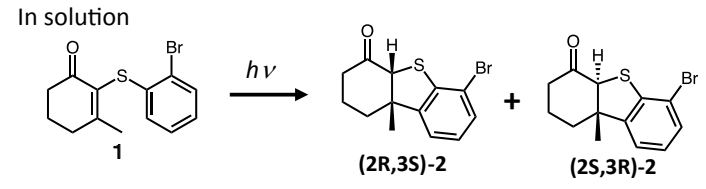

In 1:1 inclusion crystal

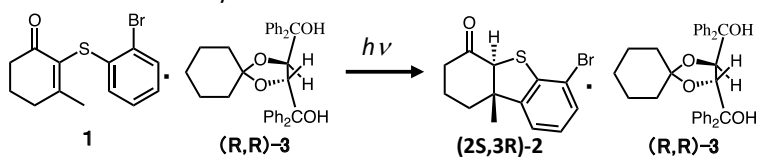

(b)

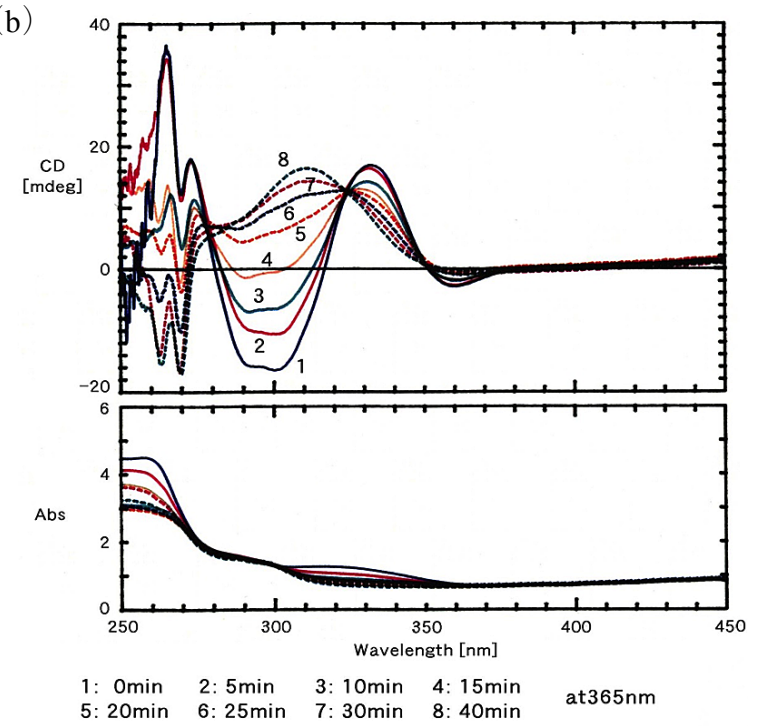

(c)

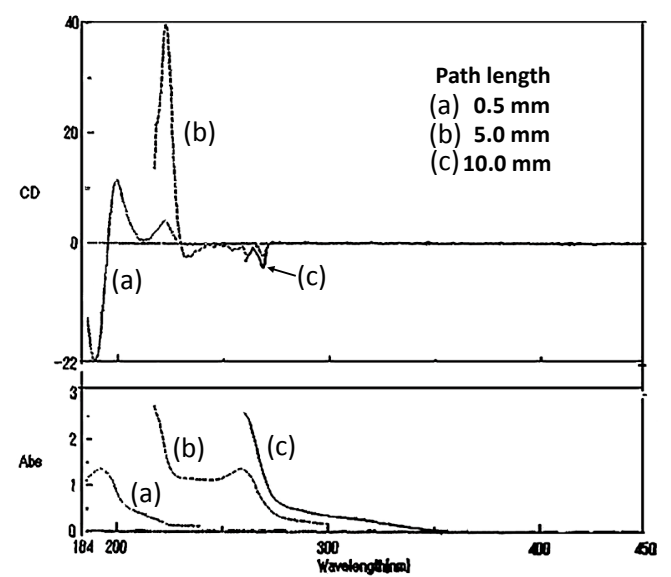

図6（a）1の溶液状態と, キラルなホスト 3 との包摂結 晶の光環化反応スキーム. (b) 固相反応過程の CD/ 吸収スペクトル. (c) 包摂結晶の溶液のスペクト ル. ((a) Photocyclization scheme of compound 1 in solution and in chiral inclusion crystals. (b) Real-time measurement of $\mathrm{CD}$ and absorption spectra during the reaction. (c) Solution spectra of the inclusion crystals.)

\section{きれいな直線関係が存在する（図 7)。}

\section{3 固体状態でのポルフィリンの凝集}

Zinc octaethylporphyrinはキラルなアミン, 1-cyclohexylethylamine と相互作用すると, 見かけはまったく変わらないの に, 固体状態であるにもかかわらず, ゆっくりとらせん 状に凝集していくことが，KBr discの CD測定から明らか

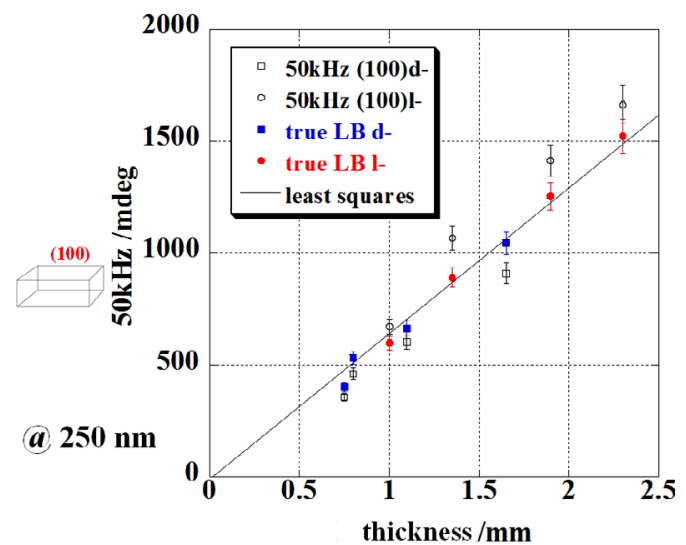

図7（100)面に平行に磨いた $d-, l-\mathrm{NaClO}_{3}$ 結晶の $250 \mathrm{~nm}$ での LB值と厚さの関係. 真および補正前の LB 值.

(True $((d)-(\square)$ and $(l)-(\bigcirc))$ and observed LB $((d)$ $(\square)$ and $(l)-(\bigcirc))$ at $250 \mathrm{~nm}$ against the thickness of sodium chlorate single crystals polished parallel to (100) face.)

(a)

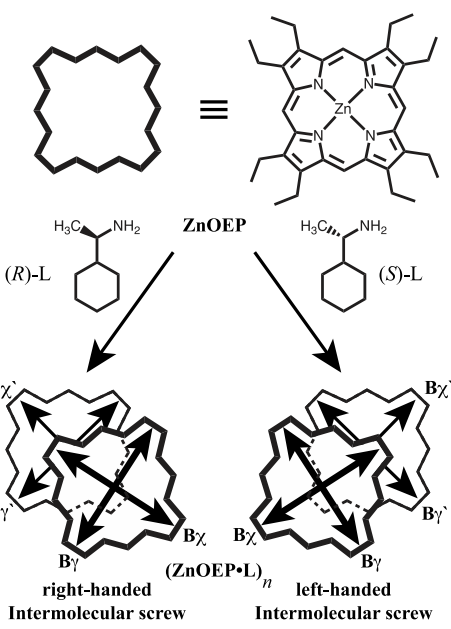

(b)

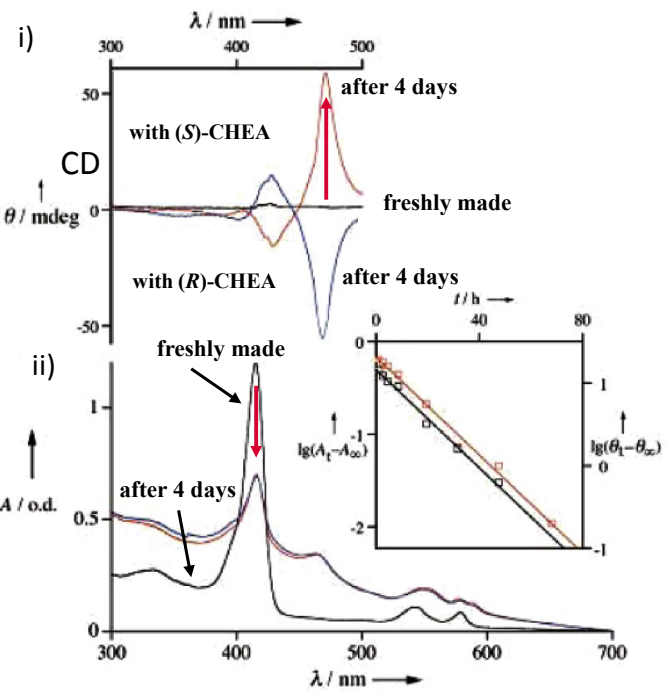

図8（a）固体状態でのZinc octaethylporphyrin とキラル な 1-cyclo-hexylethylamineの相互作用. (b) i) CD と ii）吸収スペクトルの時間変化. (Interactions of (a) Zinc octaethylporphyrin and chiral 1-cyclohexylethylamine in the solid-state. (b) Change of i) CD and ii) absorption spectra.)

日本結晶学会誌 第 60 巻 第 4 号 (2018) 
になった。アミンのキラリティーに依存して逆のキラリ ティーを示す。その強度は4 日間増大し続けた (図8). ${ }^{16)}$ 固体状態で分子が容易に再配列を起こすことを示す好 例の1つである.

\subsection{BSA タンパクの cast filmのCD}

BSA (bovine serum albumin)はじめ多くのタンパク質が, $\mathrm{BSE}$ (牛海綿状脳症)を引き起こすプリオンタンパクの ように, フィルム形成過程で $\beta$-シート構造の増加や分 子の会合が起こり, 構造が変化していると, $\mathrm{Hu}$ らが CD 分光測定から結論づけた. ${ }^{17)} し$ か彼らは, 固体状態にお ける巨視的異方性がCDスペクトルに与える影響につい ては考慮していなかった。そこで, BSAを例にとり，均 質で透明な cast filmを作り，UCSを用いて測定した．わ れわれのスペクトルは溶液状態, 膜状態ともに $\alpha$-ヘリッ クス構造を示した (図9b). $\mathrm{Hu}$ らの報告は, 巨視的異方

(a)

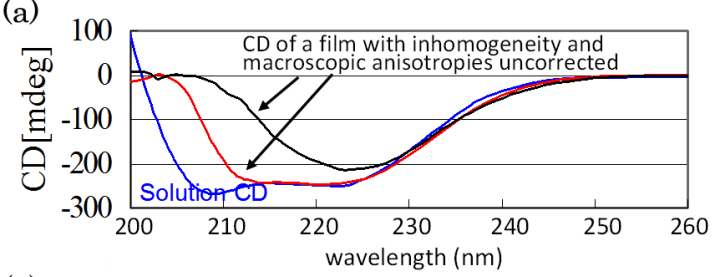

(b)

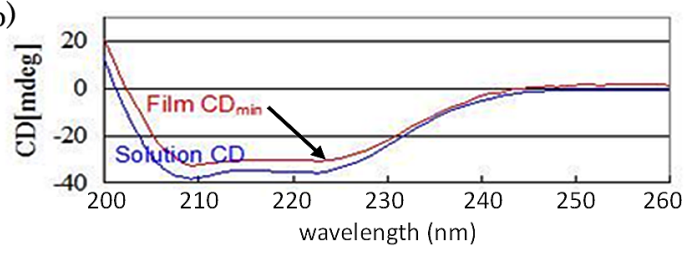

図9 BSAの溶液とフィルムのCDスペクトル. (a) 不均 質な filmの見かけのCD.（b) UCS-1 で測定した均 質な filmの真のCD. (Solution and film CD spectra of BSA. (a) Inhomogeneous films with macroscopic aniso-tropy. (b) A homogeneous film measured on UCS-1.)

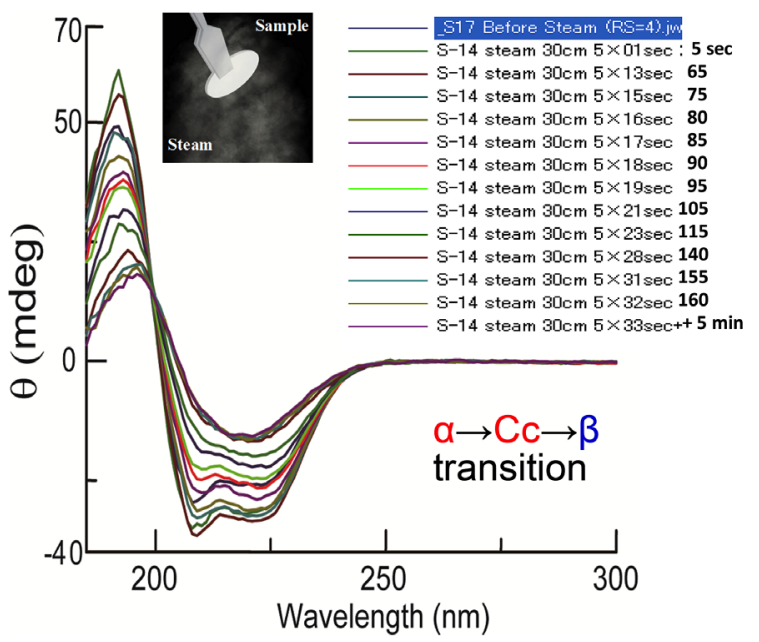

図10 ススメバチシルクの膜に水蒸気を当てたときの CDの時間変化. (Time-course change of CD spectra during the exposure to steam on a hornet silk film.)
性とサンプルの不均一性からくる偽のシグナルに基づ くことも, 不均質なサンプルを作り, 見掛けのCDスペ クトルを測定して判明することができた（図9a). ${ }^{17)}$ 一方 で, アルツハイマー病の原因タンパクの 1 つである $\beta-ア$ ミロイドA $\beta$ は, 固体状態になると $\beta$-構造に変換するこ とをUCS-1による測定で明らかにした.14)

\section{5 スズメバチシルクの二次構造変化}

スズメバチは虫のように瞢を作るが，その化学処理の 仕方で, 膜, 繊維, ジェル, 粉末などさまざまな形態・強 度のマテリアルとなる，透明な膜を作ることに成功し， その構造をUCS-1で観察した（図 10）。サンプルを農業 生物資源研究所の亀田博士から提供いただいた。驚くべ きことに，この膜に 5 秒間水蒸気を当てるだけで，4つの サブユニットからなるシルクの $\alpha$-ヘリックス構造の割 合が増大した。さらに, 5 秒間水蒸気に当てる操作を繰 り返したところ, 合計 85 秒後には coiled coil構造に, 合 計 140 秒で $\beta$-構造に変換した．膜の見かけはまったく変 わらない. 湿気なしの加熱だけでは構造変換は起こらな い. $\beta$ 構造はおそらく, $\operatorname{crossed} \beta$ 構造であろうと推定して いる. ${ }^{19)}$ 異方性による偽のシグナルが混入していないこ とも確認済である. 膜状態で起きる容易なタンパクの二 次構造変換が初めて明らかになった。この論文は国際専 門誌 Chiralityの本年 (2018年) 5 月号の表紙を飾った. ${ }^{19)}$

\section{6 gel 内に固定された 4 重螺旋 DNAの構造変化}

GelのCDはこれまで報告例がなかったが，薄く透明 なgel を作り，専用の石英板に挟むことでLD, LB, CD 測定に初めて成功した，その結果，ここでも面白い知見 を得ることができた（東大工学部吉田研究室秋元講師 らとの共同研究) ${ }^{20)}$ PNIPAAm gel は $25 \sim 55$ 度という狭 い温度範囲で, 膨潤, 収縮を繰り返す。このゲルの作る 容器の中に, 4 重螺旋を作ることのできる塩基配列をも つ single-strand DNAを膜につないだ形で入れておくと (図 11a), ゲルの熱変化に応じてDNAの4重螺旋構造が 変化することがUCS-1によるCD測定で明らかになった (図 11b). 変化はある程度反復可能である.20)

\section{7 アミロイドタンパクの凝集過程のダイナミクス}

アミロイド $\beta$ タンパク質 $(\mathrm{A} \beta)$ は, 膜貫通型タンパク 質であるアミロイド前駆体タンパク質 APPがN端の細胞

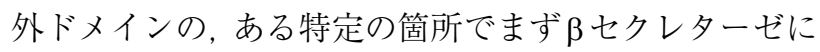
よって切断され, 次に, 細胞膜内, 膜貫通部分の端側で

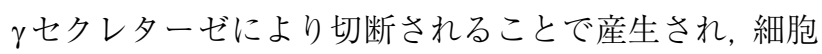
外に分泌される. $\gamma$ セクレターゼによりアミノ酸残基 Val で終わる残基数 40 個のペプチド $\mathrm{A} \beta 40$ が生成されるのが 普通であるが, 家族性アルツハイマー病患者には, アミ ノ酸残基がさらに2 個 (Ile-Ala) 伸びたところで切断さ れた $\mathrm{A} \beta 42$ が多く見られる。これら $\mathrm{A} \beta$ が脳内で凝集し, 蓄積すると, 神経細胞が変性し, 神経細胞が脱落し, 認 知症になると考えられている.UCS-1による測定から, 


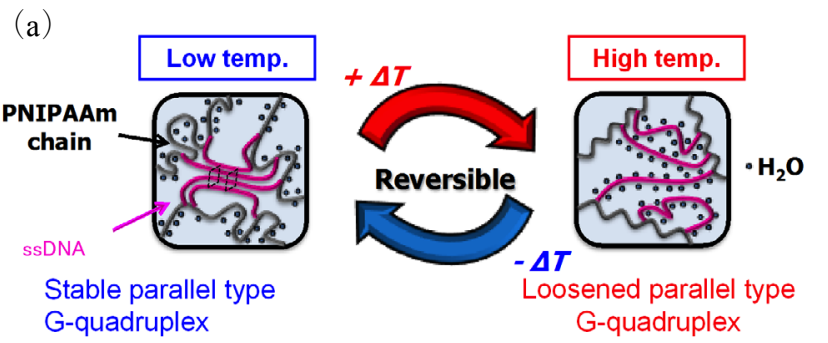

(b)

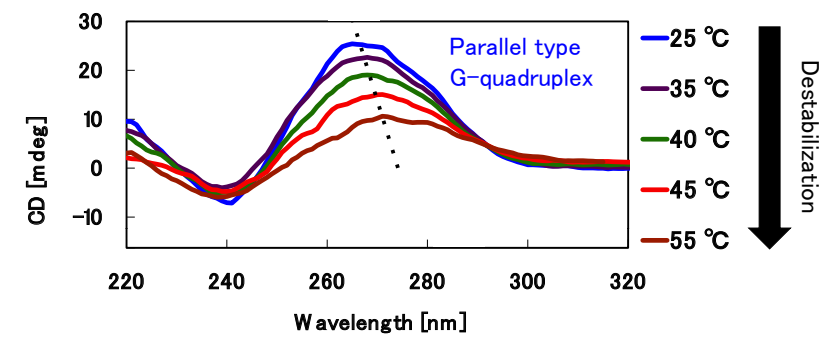

図11（a）熱感受性ヒドロゲル PNIPAAm内に結合した 単鎖DNAがゲルの膨潤／収縮に合わせて，4重螺 旋構造をとる模式図. (b) DNA 領域のCD スペク トルの温度変化.（(a) A model of a single-stranded DNA tethered inside thermoresponsive hydrogel PINAAm adopts G-quadruplex structure depending on the temperature. (b) CD spectral changes of the gel in DNAabsorption region.)

$\mathrm{A} \beta 42$ は $\mathrm{A} \beta 40$ よりも $\beta$ シート構造の割合が増えているこ とが明らかになった. ${ }^{14)}$

さらに, 垂直型 $\mathrm{CD}$ 分光計 UCS-2 用いて, 構造変化 のダイナミクスを追跡した，溶液中では $\mathrm{A} \beta 40$ は $\alpha$-へ リックス構造をとっている. 水溶液の液滴を水平な試料 台に置き，それがゆっくりと乾いて膜を形成する過程 で, タンパク質の高次構造がどのように変化していくか をリアルタイムで透過 CDで追跡した，変化前の CD スペ クトルは溶液のそれとよく似ている，図12に示したよう に，固定波長でフォトマル加電圧を測定していると，あ るところで大きく変化するところがある。この後の短い 時間にタンパク質は $\alpha$ ヘリックス構造が中心のものから $\beta$ シート構造が多い, 凝集状態の構造に変わったことが 明らかとなった。

\section{8 電荷移動錯体の崩壊過程の追跡}

ピレン Pyrene (PYR)とパラベンゾキノン p-benzoquinone （Q）はともにアキラルな有機化合物であるが, 混合溶液 から容易に濃い赤色に着色したキラルな電荷移動錯体 の結晶を生成する. ${ }^{21)}$ アキラルな分子の結晶内の配置に よるキラリティーであり，興味深い。空間群は $P 4_{1}$ ある いは $P 4_{3}$ で, 単軸晶系に属するので, 4 回軸周りには異方 性がなく, この軸方向の CD 測定に問題は生じない.し かし, 吸収係数が非常に大きく, 結晶軸に垂直な薄い面 を作るように磨くことは至難の技である，そこで，粉末 結晶の CDを測定した。この結晶はQが昇華性で, 室温

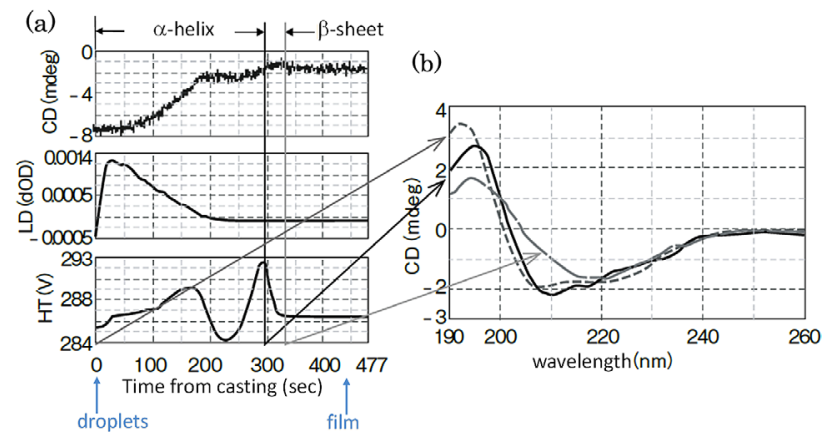

図12（a）A 340 が溶液から膜になる過程での $230 \mathrm{~nm}$ の CD, LD, HT值の時間変化と, (b) 対応した波 長スキャン CDスペクトル。 ( (a) CD, LD and HT value changes at $230 \mathrm{~nm}$ during the phase transition of A $\beta 40$ from solution to a film. (b) The corresponding wavelength scan CD spectra.)

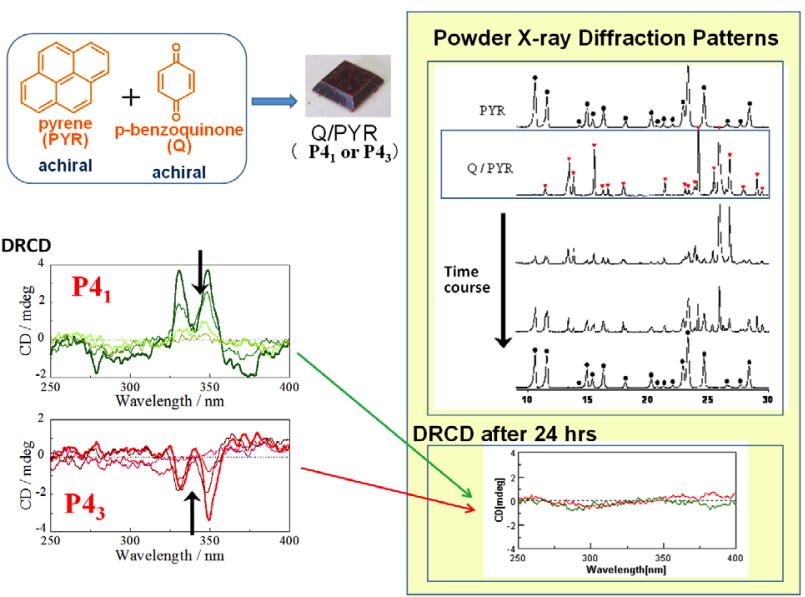

図 13 PYR と Qが作る電荷移動錯体粉末結晶の時間変 化粉末 $\mathrm{X}$ 線回折像と拡散反射 CDスペクトル.

(Time-course change of powder X-ray diffraction patterns and diffuse reflectance $\mathrm{CD}$ of the ChargeTransfer complex crystals made from PYR and Q.)

で放置しておくと次第に色が消えていく，以前，Qが失 われても結晶構造が壊れてアモルフォスになることな く成分結晶に戻ることを, ほかの電荷移動錯体で発見し ている.22) PYR-Q電荷移動錯体結晶においても，Qが昇 華して行く過程でPYR 分子が自然に再配列してPYR 結 晶に戻る。その変化の過程を粉末X線回折像と, UCS-3 を用いたDRCDで追った（図13）。シャープな回折像が 観測され, アモルフォス状態を経ずに, PYR結晶の回折 像に戻った. 粉末の拡散反射 (DR) CD は, $P 4_{1}, P 4_{3}$ に対 して互いに鏡像対称のスペクトルを示すが, どちらも， 時間の経過とともに強度を失っていき, 24 時間後, 粉末 $\mathrm{X}$ 線回折像がPYR 結晶のものになったときには強度が 0 となった21)

このような知見は, 固体状態の CD測定で初めて明ら かになることである. 粉末結晶の $\mathrm{KBr}$ disc 作製中にマト 
リックスと反応したり, 粉砕過程で結晶系が変換したり する例をわれわれは見つけている。粉末結晶を水平試料 台に置いただけでin situで測定できるDRCD は有用であ ると考えている.

\section{5. おわりに}

特別にデザインされた装置で, 特殊な方法で測定すれ ば, 巨視的異方性をもつ凝集状態の試料のキラリティー や構造変化のダイナミクスを明らかにすることができ る.これはアルツハイマー病などの神経変性疾患, 光学 材料など幅広い応用が可能である。測定自体それほど難 しいわけではなく，1970年代前半に考案した $\mathrm{KBr}$ disc 法 による CD測定のように, 多くの人が凝集状態のキラリ ティー研究に使ってくれることを願っている. 長年にわ たる研究過程で多くの共同研究者に恵まれ, この場を借 りて改めて謝意を表したい.

今回は得られたシグナルの中から, 異方性によるシグ ナルを除去するUCSについてのみ解説した。われわれ

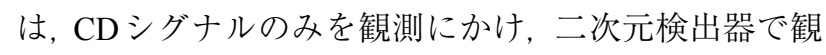
測するとこで, m secの桁で測定できる装置を開発中で ある. 測定されたスペクトルは真のスペクトルで, 演算 処理も不要である (国内, 米特許取得済).今後, この装 置も何とか発展させたいと願っている。

\section{文 献}

1) H. J. Mueller: Opt. Soc. Am. 38, 661 (1948).

2) M. Born and E. Wolf: Principles of Optics 2nd ed, Chap 1, p.30, PERGAMON PRESS, Oxford (1964)

3) R. Kuroda, T. Harada and Y. Shindo: Rev. Sci. Inst. 72, 3802 (2001).

4) R. Kuroda: Ph. D. thesis, Tokyo University (1975).

5) R. Kuroda and Y. Saito: Bull. Chem. Soc. Japan 49, 433 (1976).

6) R. Kuroda: Circular Dichroism: Principles and Applications, Second Edition, ed. N. Berova, K. Nakanishi and R. W. Woody, Chapter 6, p.159, John Willey \& Sons. Inc. (2000).

7) A. F. Drake, R. Kuroda and S. F. Mason: J. Chem. Soc. Dalton Trans. 1095 (1979).

8) R. Kuroda and T. Honma: Chirality 12, 269 (2000).
9) R. Kuroda: Chiral Photochemistry, ed. Y. Inoue, V. Ramamurthy, p.385, Marcel Dekker, Inc. (2004).

10) R. Kuroda: NATO Science for Peace and Security Series Engineering Crystallography: From Molecule to Crystal to Functional Form, ed. K. J. Roberts, R. Docherty and R. Tamura, Chapter 24, p.395, Springer (2017).

11) M. J. B. Tuis-Schneider and M. F. Maestrer: J. Mol. Biol. 52521 (1970).

12) T. Harada, H. Hayakawa and R. Kuroda: Rev. Sci. Instrum. 79, 073103 (2008).

13) T. Harada T, Y. Miyoshi and R. Kuroda: Rev. Sci. Instrum. 80, 046101 (2009).

14) T. Harada and R. Kuroda: Biopolymers 95, 127 (2011).

15) T. Harada, T. Sato and R. Kuroda: Chem. Phys. Lett. 413, 445 (2005).

16) V. V. Borovkov, T. Harada, G. A. Hembury, Y. Inoue and R. Kuroda: Angew. Chem. Int. Ed., 42, 1746 (2003).

17) H. Hu, Q. Li, H. Cheng and H. Du: Biopolymers 62, 15 (2001).

18) T. Harada and R. Kuroda: Chem. Lett. 31, 326 (2002).

19) R. Kuroda and T. Kameda: Chirality, 50, 541 (2018). Journal cover

20) E. Hasuikea, A. M. Akimoto, R. Kuroda, K. Matsukawa, Y. Hirutac, H. Kanazawac and R. Yoshida: Chem. Commun. 53, 3142 (2017).

21) N. Asano, T. Harada, T. Sato, N. Tajima and R. Kuroda: Chem. Commun. 899 (2009).

22) R. Kuroda, Y. Imai, and N. Tajima: Chem. Commun. 2848 (2002).

23) R. Kuroda and Y. Imai: Mendeleev Comm. (dedicated to Homochirality discovered by Louis Pasteur in 1848), 148 (2003).

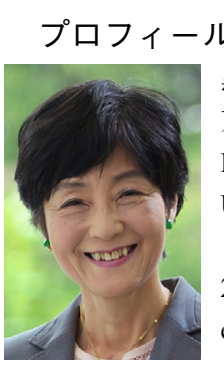

黑田玲子 Reiko KURODA 東京理科大学研究推進機構総合研究院

Research Institute for Science and Technology, Tokyo University of Science 干 278-8510 千葉県野田市山崎 2641

2641 Yamazaki, Noda-shi, Chiba 278-8510, Japan e-mail: rkuroda@rs.tus.ac.jp 最終学歴: 東京大学理学系研究科博士課程 専門分野: 化学, 結晶学, 分光学, 発生生物学 現在の研究テーマ: カイロモルフォロジー研究 巻貝の巻き型決定遺伝子の同定から決定機構の 解明; 多形結晶間の固体状態での変換とキラリ ティー転写 ; 固体状態でのキラリティー分光測 定など 